\title{
Crystallization of Low Temperature Fired Glass/Ceramic Composite
}

\author{
Yoshihiko IMANAKA, Shigenori AOKI, Nobuo KAMEHARA and Koichi NIWA \\ $\left(\begin{array}{l}\text { Fujitsu Laboratories Ltd., Atsugi } \\ 10-1 \text {, Morinosato-Wakamiya, Atsugi-shi, Kanagawa 243-01 }\end{array}\right)$
}

低温焼成ガラスーセラミックス複合材料の結晶化

今中佳彦・青木重憲・亀原伸男・丹羽紘一

（(株）富士通研究所 厚木研究所）

\begin{abstract}
The crystallization of glass/ceramic composites was examined, using borosilicate glass and several of kinds ceramic powders (alumina, aluminum nitride, cordierite, magnesia, forsterite, steatite, silicon nitride). Most composite specimens composed of borosilicate glass and ceramics formed cristobalite during firing, whereas those containing alumina or aluminum nitride did not form any crystal. The addition of alumina or aluminum nitride powder is effective means of preventing the formation of cristobalite.

[Received March 7, 1987; Accepted June 16, 1987]
\end{abstract} Key-words : Alumina-glass system, $\mathrm{B}_{2} \mathrm{O}_{3}-\mathrm{SiO}_{2}$ glass, Cristobalite, Glass/ceramic composite, Thermal expansion
coefficient (TEC)

\section{Introduction}

The ceramic circuit boards used for high speed computer require a lower dielectric constant and a lower thermal expansion which enable the realization of high-speed signal propagation and highdensity direct mounting of bare LSI chips. ${ }^{1)}$ And also to lowering the firing temperature makes it possible to fire the board with printed copper or gold conductor patterns.

The optimum firing temperatures of glass/ ceramic composite can be controlled by using glass with various softening temperatures. The dielectric constant and thermal expansion can also be controlled by mixing glass and ceramic materials.

Borosilicate glass has a relatively low dielectric constant and a softening point that is easily controllable by changing the $\mathrm{B}_{2} \mathrm{O}_{3} / \mathrm{SiO}_{2}$ ratio. The thermal expansion coefficient is lower than that of silicon. Therefore the combination of $\mathrm{B}_{2} \mathrm{O}_{3}-\mathrm{SiO}_{2}$ glass and suitable ceramics will result in properties which make this material well suited to use in future circuit boards.

The major problem in glass/ceramic composite, however, is the formation of a crystal which changes the properties of the glass/ceramic composite thus degrading the material. Therefore, if crystallization occurs, it becomes very difficult to obtain the required properties because of the differences in the properties of glass and formed crystals.
The crystallization of $\mathrm{B}_{2} \mathrm{O}_{3}-\mathrm{SiO}_{2}$ glass in glass/ ceramic composite and the effect of crystallization on the thermal expansion coefficient were studied changing the ceramic materials. A combination of glass and ceramic which does not form any crystals was introduced.

\section{Experimental procedure}

The composition of the borosilicate glass used in this study is shown in Table 1. The softening point of the glass is $800^{\circ} \mathrm{C}$ and the average particle size is $4 \mu \mathrm{m}$. The ceramic powders used were alumina, aluminum nitride, cordierite, magnesia, forsterite, steatite and silicon nitride. The average particle size of all the powders was about $3 \mu \mathrm{m}$. Table 2 shows the composition of the glass/ceramic composite. The volume ratio of glass to ceramics is kept at a constant $13 / 7$. Glass and ceramic powder were milled with binder and solvent for $20 \mathrm{~h}$ in a plastic mill pot. The slurry

Table 1. Composition of borosilicate glass.

\begin{tabular}{l|r}
\hline Component & $(w t \%)$ \\
\hline $\mathrm{SiO}_{2}$ & 80.5 \\
\hline $\mathrm{B}_{2} \mathrm{O}_{3}$ & 12.9 \\
\hline $\mathrm{Na}_{2} \mathrm{O}$ & 3.8 \\
\hline $\mathrm{Al}_{2} \mathrm{O}_{3}$ & 2.2 \\
\hline $\mathrm{K}_{2} \mathrm{O}$ & 0.4 \\
\hline $\mathrm{CaO}$ & 0.2 \\
\hline
\end{tabular}


Table 2. Composition of glass/ceramic composite.

\begin{tabular}{c|c|c}
\hline \multicolumn{1}{c|}{ System } & Ceramics & Glass \\
\hline Alumina - Glass & 50.0 & 50.0 \\
\hline $\begin{array}{c}\text { Aluminum } \\
\text { nitride - Glass }\end{array}$ & 45.3 & 54.7 \\
\hline $\begin{array}{c}\text { Cordierite -Glass } \\
\begin{array}{c}\text { Magnesia - Glass } \\
\text { Forsterite -Glass }\end{array}\end{array}$ & 38.6 & 61.4 \\
\hline $\begin{array}{c}\text { Steatite -Glass } \\
\text { - }\end{array}$ & 40.4 & 52.9 \\
\hline $\begin{array}{c}\text { Silicon } \\
\text { nitride - Glass }\end{array}$ & 44.6 & 58.7 \\
\hline
\end{tabular}

was cast using the doctor blade method, the casting being $500 \mu \mathrm{m}$ thick. The cast green sheets were laminated, giving a $1 \mathrm{~mm}$ thick, then fired in a $\mathrm{N}_{2}$ atmosphere at $1000^{\circ} \mathrm{C}$ for $5 \mathrm{~h}$. The heating rate was $200^{\circ} \mathrm{C} / \mathrm{h}$.

The formation of crystal in the glass/ceramic composite was examined using X-ray diffraction analysis; $\mathrm{Cu}$ target, $30 \mathrm{kV}, 10 \mathrm{~mA}$. The thermal expansion coefficient was measured using a push rod dilatometer. Silica glass was used as the standard specimen. The heating rate for TEC measurement was $5^{\circ} \mathrm{C} / \mathrm{min}$. The temperature ranged from $0^{\circ}$ to $250^{\circ} \mathrm{C}$.

\section{Results and discussion}

The results of X-ray diffraction analysis show that many combinations of borosilicate glass and ceramics formed cristobalite (ex. Fig. 1 cordierite-glass system). The glass/ceramic composite systems that include alumina or aluminum nitride, however, did not form any crystal, as shown in Fig. 2. The peculiar curve of amorphous glass known as halo was observed in those specimens that did not form any crystal. In the

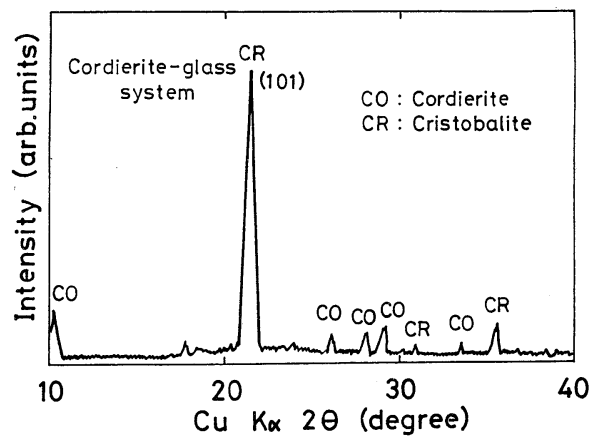

Fig. 1 X-ray diffraction pattern of cordierite-glass system.

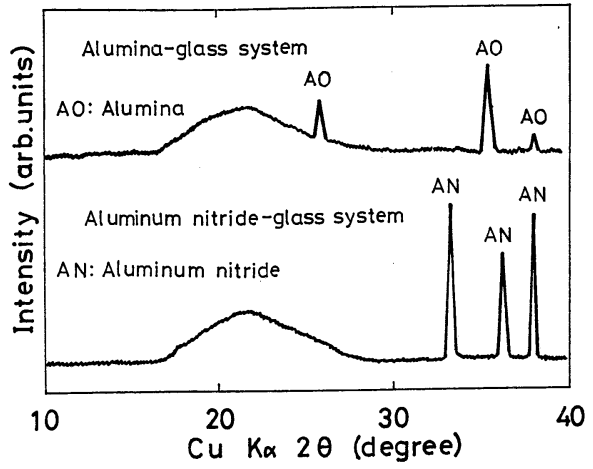

Fig. 2. X-ray diffration patterns of alumina-glass and aluminum nitride-glass systems.

specimens that formed cristobarite, a (101) peak of cristobalite appears at $20^{\circ}-22^{\circ}$ ( Cu target) and the halo disappears. The temperature at which the crystallization occurs is above $800^{\circ} \mathrm{C}$.

The cordierite-glass system specimen shows a high thermal expansion coefficient (TEC). The calculated TEC of the system using Turner equation is $2-3 \times 10^{-6} /{ }^{\circ} \mathrm{C}$, which is slightly lower than that of silicon. In the same system, the measured TEC is $17 \times 10^{-6} /{ }^{\circ} \mathrm{C}$, which is 7 times higher than the calculated value. The TEC curve of cordierite-glass system is shown in Fig. 3. In

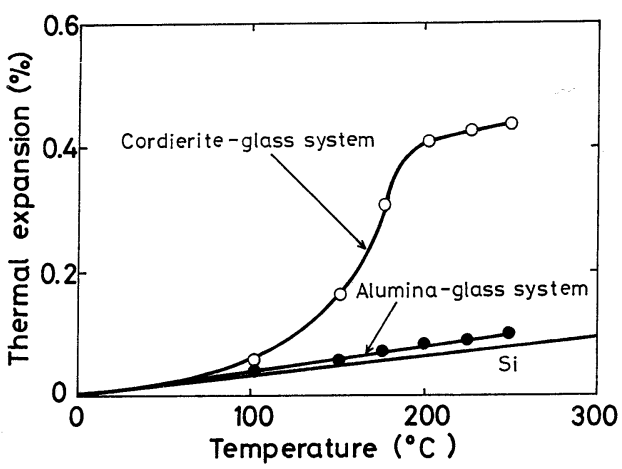

Fig. 3. The comparison of the TEC curves both cordierite-glass and alumina-glass systems with $\mathrm{Si}$ crystal.

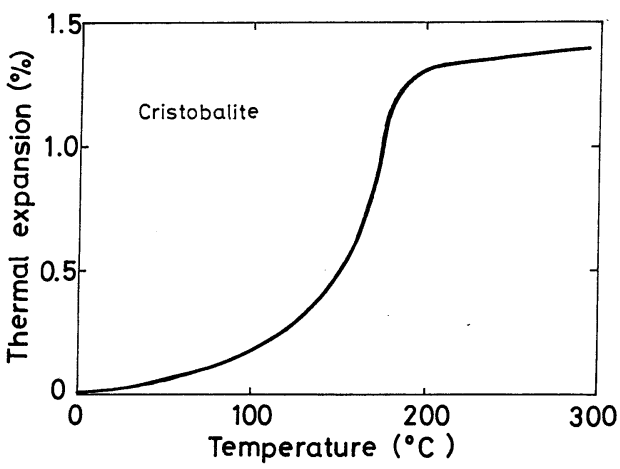

Fig. 4. The TEC curve of cristobalite. 
Table 3. Thermal expansion coefficient of glass/ ceramic composite.

\begin{tabular}{|c|c|c|}
\hline System & Calculated value & Measured value \\
\hline Alumina & 4.6 & 4.0 \\
\hline $\begin{array}{l}\text { Aluminum } \\
\text { nitride - Glass }\end{array}$ & 3.6 & 3.5 \\
\hline $\begin{array}{r}\text { Cordierite } \\
\text { - Glass } \\
\end{array}$ & 2.9 & 17.0 \\
\hline $\begin{aligned} & \text { Magnesia } \\
& \text { - Glass } \\
&\end{aligned}$ & 5.7 & 18.3 \\
\hline $\begin{array}{r}\text { Forsterite } \\
- \text { Glass } \\
\end{array}$ & 5.7 & 18.2 \\
\hline $\begin{array}{l}\text { Steatite } \\
\text { - Glass } \\
\end{array}$ & 4.6 & 17.4 \\
\hline $\begin{array}{l}\text { Silicon } \\
\text { nitride - Glass }\end{array}$ & 3.1 & 17.1 \\
\hline $\begin{array}{l}\text { Turner equation } \\
\qquad \alpha=\frac{\sum \alpha_{\mathrm{i}} v_{\mathrm{i}}}{\sum v_{\mathrm{i}} E_{\mathrm{i}}}\end{array}$ & \multicolumn{2}{|c|}{$\begin{array}{l}\alpha: \text { Thermal expansion } \\
v: \text { Volume ratio } \\
\text { E:Young's modulus }\end{array}$} \\
\hline
\end{tabular}

general, the TEC curve is almost straight in a wide temperature range (ex. the alumina-glass system, Si). But the figure shows the straight lines only in both region, below $100^{\circ} \mathrm{C}$ and above $200^{\circ} \mathrm{C}$. Between $100^{\circ}-200^{\circ} \mathrm{C}$ the $\mathrm{TEC}$ shows very steep curve which is very similar to that of cristobalite, shown in Fig. 4.

Cristobalite is a polymorphism of silica having an $\alpha$-phase below $100^{\circ} \mathrm{C}$ and a $\beta$-phase above $200^{\circ} \mathrm{C}$. Rearrangement from $\alpha$-phase to $\beta$-phase is reversible and the specific gravity changes between 2.320 and 2.217 in the $\alpha$ to $\beta$ transformation. This results in a rapid change in the TEC curve shown in Fig. 4. The TEC both measured and calculated in the temperatures range from $0^{\circ}$ to $250^{\circ} \mathrm{C}$ for other glass/ceramic composite systems are shown in Table 3. Evident differences between the measured and calculated TEC can be seen for the specimens with cristobalite in their matrix. In alumina and aluminum nitride, however, the both calculated and measured TEC are almost the same. The results shown in Figs. 1-3 and Table 3 suggest that the TEC of glass/ceramic composite is influenced directly by newly formed crystals.

To clarify the effect of alumina or aluminum nitride additions on crystallization of borosilicate glass the alumina powder was added to cordierite-glass system. The addition of $5 \mathrm{wt} \%$ alumina results in lower intensity of cristobalite in X-ray diffraction peak. Figure 5 shows the TEC curve of cordierite-glass system with alumina. The steep change in the thermal expansion between $100^{\circ}-200^{\circ} \mathrm{C}$ becomes gentle and the TEC

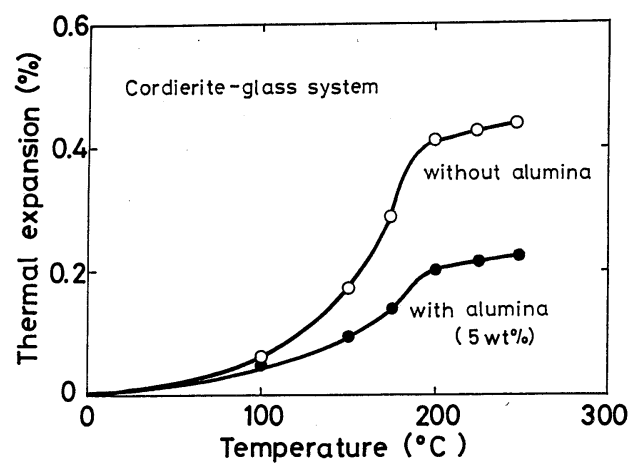

Fig. 5. The TEC curve of alumina added cordieriteglass lass system.

decreased to $47 \%$ of that of the basic system. From these results, it is evident that the addition of alumina can prevent the formation of cristobalite.

Previously, cristobalite formation in glass/ ceramic composites has been reported in a partially stabilized zirconia-borosilicate glass system ${ }^{3)}$ and in an alumina-lead borosilicate glass system. ${ }^{4)}$ It is certain that the cristobalite crystallization is clearly observed in a glass/ceramic composite system that includes borosilicate glass but does not include a alumina or aluminum nitride.

- The prevention of crystallization by adding alumina or aluminum nitride may have some relation with aluminum ions. However, further experimentation is necessary to determine the mechanism of the prevention.

\section{Summary}

The crystallization of glass/ceramic composite was examined, using borosilicate glass and several kinds of ceramic powders. Most composite systems consisted of borosilicate glass and ceramics formed cristobalite during firing, whereas those specimens that include alumina or aluminum nitride did not form any crystal.

The addition of alumina or a aluminum nitride powder is effective means of preventing the formation of cristobalite. The reason for this may be related to aluminum ions.

\section{Reference}

1) K. Niwa, N. Kamehara and K. Murakawa, Fall Meetings of Am. Ceram. Soc. (1981).

2) N. Kamehara, K. Kurihara and K. Niwa, Annual Meetings of Am. Ceram. Soc. (1985).

3) M. Iwamura and Y. Koga, Yogyo-Kyokai-Shi, 81, 271-80 (1973).

4) Y. Shimada, K. Utsumi, M. Suzuki, H. Takamizawa, M. Nitta and T. Watari, Trans. Components, Hybrids, Manuf. Technol., Vol. CHMT-6, No.4, 382-88 (1983). 